\title{
AN UNKNOWN DIVAN POET OF 16TH CENTURY: PIRKAL
}

İslam KÜÇÜK *

* Başarı Üniversitesi E-mail: islamkucuk@basari.edu.tr

Copyright (c) 2015 İslam KÜÇÜK. This is an open access article distributed under the Eurasian Academy of Sciences License, which permits unrestricted use, distribution, and reproduction in any medium, provided the original work is properly cited.

\begin{abstract}
This study is on Pirkal who was not mentioned in the books about literature, and his Divan. Today we have the only and the original copy of the book. The book dates back to the 16th century, so some of its pages has lost and some have been destroyed. In this study, the information about his literary and intellectual personalities were given and also some of the poems were written in current alphabet.In addition, the Divan of looking at the poems of the poet with a love of Ahl al-Bayt see that the upper level.In particular, Hz.Ali affection and love is expressed in poems.
\end{abstract}

Keywords: Pirkal, the poem of Divan, Literature, Poem

JEL-Clasification:

\section{Asrın Bilinmeyen Bir Divan Şairi: Pirkal}

\section{ÖZET}

Bu çalışma, edebiyat tarihlerinde yer almamış bir şair; Pirkâl ve Divan'1 üzerinedir. Elimizde Divan'ın tek ve asıl nüshası mevcuttur. Eserin 16.yüzyıla ait olması günümüze kadar gelen süreçte bazı sayfalarının herhangi bir sebeple eksilmesine ve tahrip olmasına yol açmıştır. Çalışmada Pirkâl'in edebî ve fikrî kişiliği hakkında bilgi verilmiş, Divan'ındaki bazı şiirler günümüz harflerine aktarılmıştır. Ayrıca, Divanındaki şiirlerine baktığımızda şairin üst düzeyde ehl-i beyt sevgisine sahip olduğunu görmekteyiz. Özellikle, Hz.Ali muhabbeti ve sevgisi şiirlerde ifade edilmektedir

Anahtar Kelimeler: Pirkâl, Divan Şiiri, Edebiyat, Şiir

\section{GíRIŞ}

Pirkâl, tezkirelerde ve edebiyat tarihi ile ilgili eserlerde adı zikredilmeyen bir divan şairidir. Eser üzerine ilk ve tek bilimsel çalışma İslam KÜÇÜK ${ }^{1}$ tarafından yapılmıştır. Pirkâl'in yaşamıyla ilgili elimizde yazılı bir bilgi mevcut değildir. Yapılan taramalar neticesinde de $\mathrm{o}$ döneme ait tezkirelerde, bahsi geçen şair hakkında hiçbir bilgiye rastlanmamıştır. (Kılıç,

\footnotetext{
${ }^{1}$ İslam Küçük (2008). Pîrkâl Dîvânı (İnceleme-Metin). Yüksek Lisans Tezi, Fatih Üniversitesi Sosyal Bilimler Enstitüsü, İstanbul.
} 
2010; Kutluk, 2014; Sungurhan, 1994; İsen, 1994) Dolayısıyla yaşamı ve edebi şahsiyeti hakkında bilgi verilirken kullanmış olduğumuz beyitler mevcut çalışmadan alınmıştır.

Pirkâl'in yaşadığı döneme bakacak olursak 16.yüzyılda yaşadığına dair Divan'ında bazı bilgiler yer almaktadır. Divan'ın nesir kısımlarından birinde Kanuni Sultan Süleyman'a atıfta bulunmaktadır: "Der beyân-1 ahvâl-i pâk şâh-1 İslam Sultan Süleymân u vezîr-i âsaf-1 devrân fütûr-1 insân-1 kâmildür.'(Küçük, 2008: 37) Ayrıca Pirkâl, eserinde Divân'ını dokuz yüz elli dört tarihinde tertip ettiğinden bahsetmektedir.

Bu tertîb ü bu târîh u bu dîvân

Dokuz yüz elli dört olmışdur ey cân (Mes. 6/1)

Şairin muhtemelen Irak, İsfahan ve Belh şehirlerini dolaştığını beyitteki kendi ifadelerinden anlamaktayız.

Gel beru ey Pirkâl şimden gerü sen sâkin ol

Nice bir seyr-i Irak u ba-Sifahân yâhû Belh (G. 45/5)

Eserinden tespit ettiğimiz kadarıyla Pirkâl'in tasavvufî yönü ağır basan bir Divan şairi olduğunu görmekteyiz. Şair neredeyse Divan'ın başından sonuna kadar birçok yerde Hz.Ali'ye olan sevgisini dile getirmektedir. Hz.Ali'ye atfedilen " Haydar” ifadesini ve yine O’na ait olan manevî değerleri kaleme aldığını görmekteyiz.

Dâimâ dil kal'asını feth iden Hayydar misâl

Ahmed-i mürsel midür yâhûd kim ol Hayydar midur (G. 51/2)

Cevher-i aşkı bilürsen gel beri

Kandedür gelsün beru Hayydar-şinâs (G. 88/2)

Zülfikâr u Düldüli Kamber bilür

Pirkâl sultân-1 aşkdur ârif Hayydar-şinâs (G. 88/5)

Pirkâl'in, Divân'ında Fazlullah Hurûfî'ye atıfta bulunduğunu ve Hurûfîliğin ${ }^{2}$ inanç sistemine ait birçok düşünceyi beyitlerinde dile getirdiğini müşahade etmekteyiz. Buradan hareketle Pirkâl'in ya Hurûfîliğin düşünce felsefesine tamamen sahip olduğunu ya da Hurûfîliğe karş1 ilgi duyduğunu düşünmekteyiz.

Feyz-i Fazl-1 Hakkdurur üstâdımuz

Âyet-i innî ene'llahdur bizüm evrâdımuz (G. 80/1)

\footnotetext{
${ }^{2}$ Hurufilliğin temeli, eski çağlardan gelen ve harflerle sayıların kutsallığını kabul edip bunlara çeşitli sembolik anlamlar yükleyen anlayışa dayanır. Çok eskiden beri tabiatta varlığı kabul edilen gizli güçler şekil ve harflerle ifade edilmeye çalışılmış, sonuçta tabiat bilimlerinden önce efsun, tılsım, sihir gibi tekniklerle ' hurûf 'ilmi adı altında sözde ilimler ortaya çıkmıştır. Hurûfîliğin ne zaman ve nasıl doğduğu kesin olarak bilinmemekle birlikte gerçek anlamıyla milattan önce IV ve III. yüzyıllardan itibaren Ortadoğu'daki Helenistik-gnostik karakterli dinlerde ortaya çıktığı görülmektedir. Hüsamettin Aksu. (1998). Hurufilik. c. XVIII, Türkiye Diyanet Vakfi İslam Ansiklopedisi, İstanbul, s. 408.
} 
Anun zâtı vü ilmi küll-i Hakdur

Muayyendür muhakkakdur bu âşık (G. 133/1)

Hakkı her şeyde zâhir gördüm ey cân

Bes oldum ta'zîm ü tekrîme lâyık (G. 133/2)

Benim Furkân benim seb’ül-mesânî ${ }^{3}$

Benim bilgil kitâbu'llâh-1 nâtık (G. 133/3)

Hurufiler, insanı Allah'ın dünyadaki bir temsili, bir yansıması olarak görürler. Bu nedenle insanı merkeze alan ve ona aşırıcı derecede kıymet veren bir düşünce yapısına sahiptirler. Özellikle bu noktada Pirkal'in, gazellerinin mahlas beyitlerinde kendisini yüceltici ifadeleri sıkça kullandığını görmekteyiz. Hurufilik ile ilgili ilave bilgiler edinebilmek için farklı kaynaklara da başvurulabilir. (Usluer, 2009; Usluer vd. 2014; Ünver, 2003; Gölpınarlı, 1973; Kansızoğlu, 2004; Bashir, 2012; Tökel, 2003; Muhtar, 1986; Gölpınarlı, 1964 )

Hâkle yeksân olurken bu gönül ey Pirkal

Aşk irüp ol miskîni sultân eder her rûz u şeb (G. 10/5)

Vahdet-âbâd-1 fenâda bî-nişân

Pirkalidür ârif-i sultân-1 aktâb (G. 13/8)

Bende-i pîr-i tarîkat Pirkal

Âdet ü âyîn elinden el-gıyâs (G. 25/5)

Şair, Divân'ında "Pirkâl" mahlasının dışında bir defaya mahsus olmak üzere "Pir Kulı" mahlasını kullanmaktadır.

Senün aşkun diler $\underline{P \text { ir Kulı } \text { dâim }}$

Canâ benden temennâdur kidemden (G. 181/5)

Şair, Divan'ın bazı yerlerinde farklı mutasavvıfların isimlerini zikretmektedir. Bu mutasavviflardan biri de Pîr Ahmet'tir. Şairin Pîr Ahmet'ten mühim derecede etkilendiğini görmekteyiz. Çünkü Divan'ın kırk yedinci gazelini 'Pîr Ahmet' redifiyle yazmış ve bu gazelde onu müthiş derecede övmüştür.

\section{Gazel 47}

Dürr-i ilm-i meânîdür pîr Ahmed

Muhakkak nûr u nûrânî pîr Ahmed

[= Pir Ahmed, mana ilminin incisidir ve şüphesiz nurludur. ]

Künûz-1 bahr-i ummân-1 ledünnî

Zamânda Hızr-i sânîdür pîr Ahmed

[=Sonsuz denizlerin hazinesi olan Pir Ahmed, zamanın ikinci Hızır'ıdır. ]

\footnotetext{
3 “Seb’ül-mesânî”, iki defa nazil olan ve yedi âyetten ibaret bulunan Fâtiha Suresidir.
} 
Bu eşbâh u cemâd anun temâmet

Hakîkatde dil ü cânı pîr Ahmed

[= Pir Ahmed, hakikatte tüm bu yaratılmışların (varlıklar) canı ve gönlüdür. ]

Hicâb-1 zulmeti ref itdi külli

İçüpdür âb-1 hayvânı pîr Ahmed

[= Hayat suyunu içmiş olan Pir Ahmed, zulmetin utancını tamamen ortadan kaldırdı. ]

Pîr Ahmed hâdî-i ehl-i cihândur

Cihânun kutb-1 devrânı pîr Ahmed

[= Pir Ahmed, dünya ehlinin yol göstericisi ve zamanın kutbudur. ]

Yüzin sür pâyine ey Pirkal sen

Kim ide sana ihsânı pîr Ahmed

[=Ey Pirkal! Sen, Pir Ahmed'in ayağına yüzünü sür. Ondan başka sana kim ihsanda bulunabilir? ]

Pirkal, Divanı'nda Farsça şiirlere de yer vermiştir.
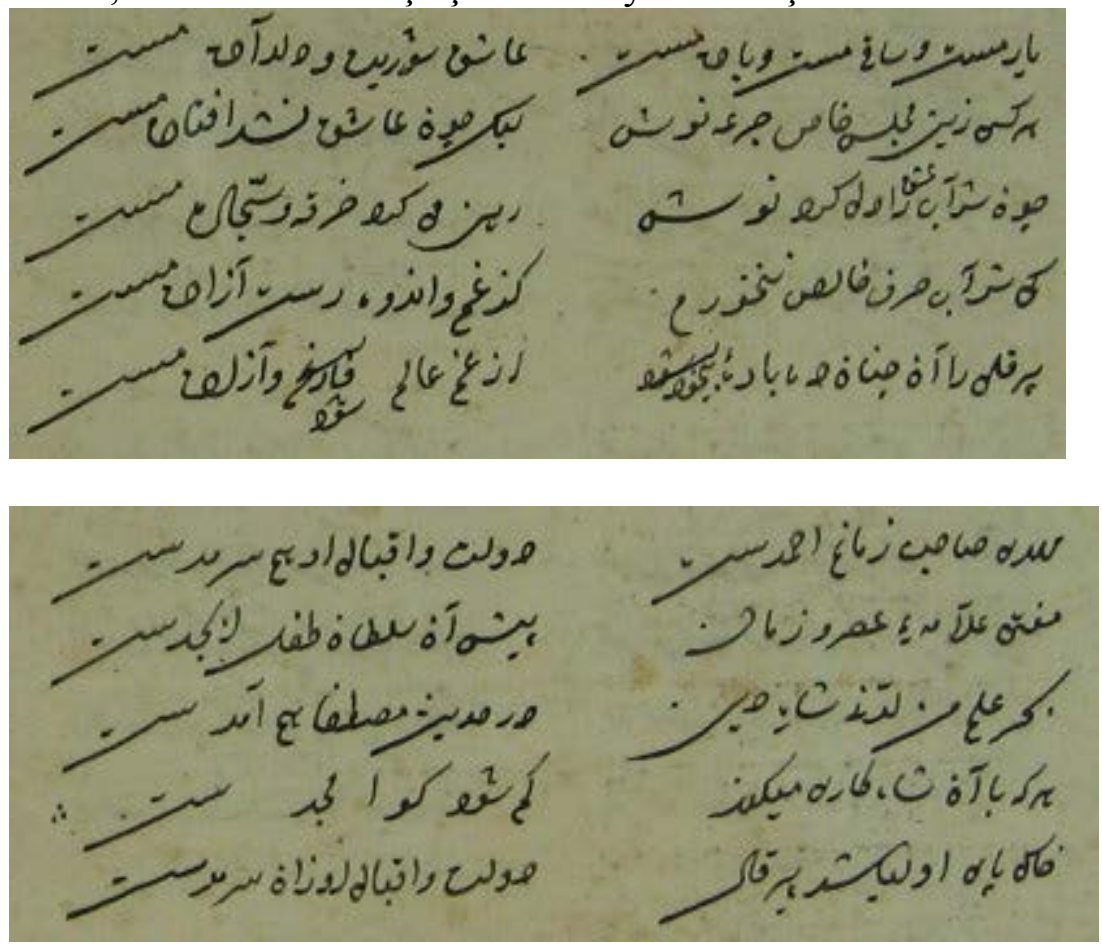

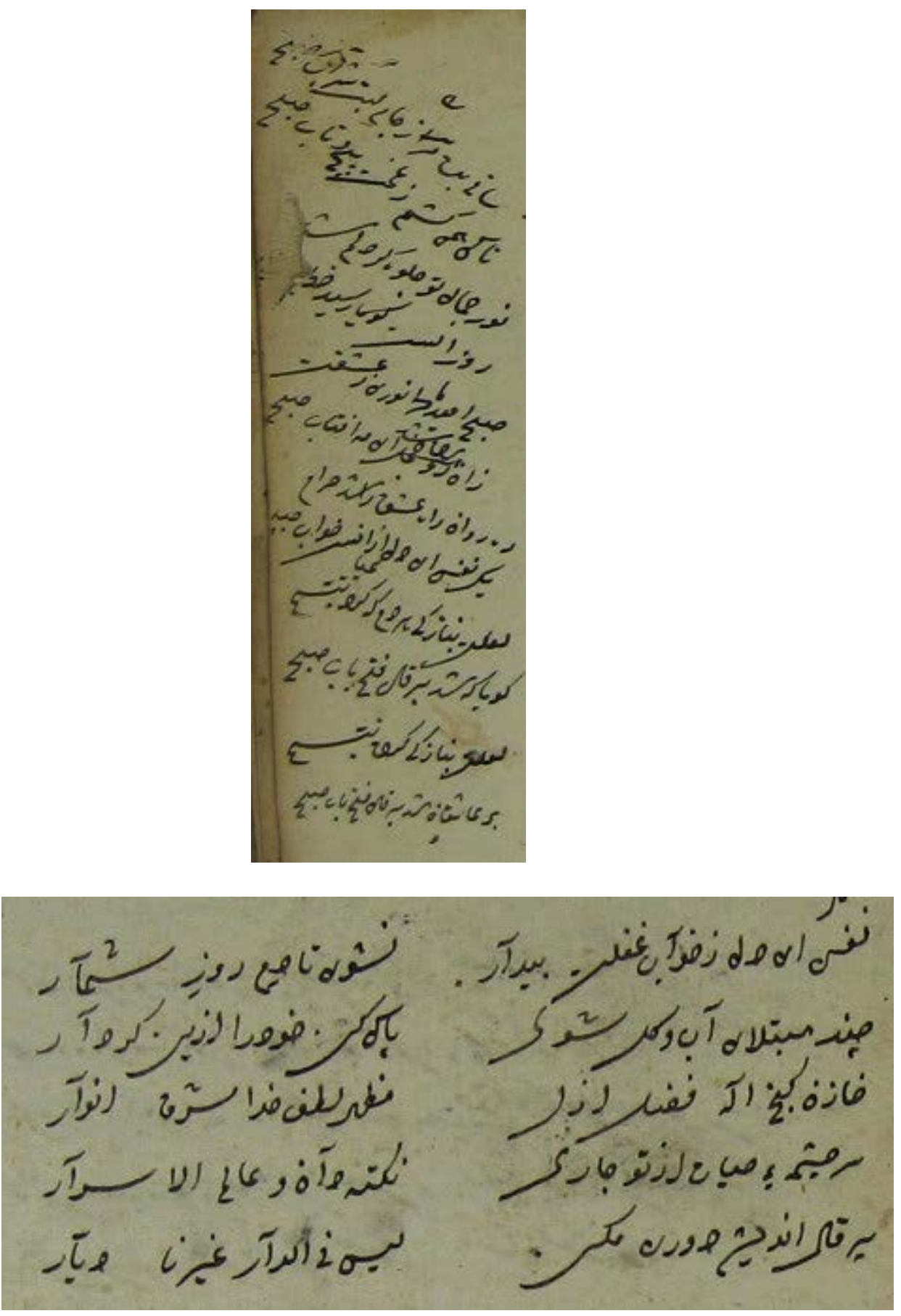


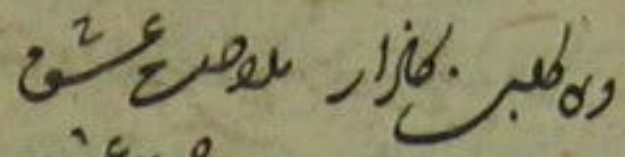
oو

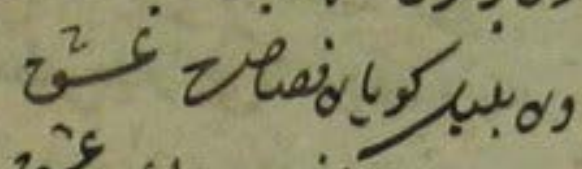
שـ

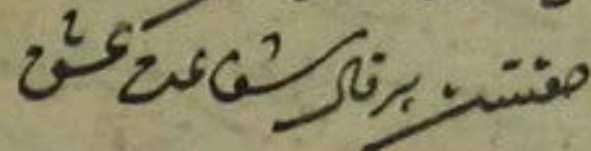

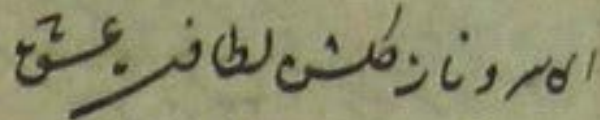

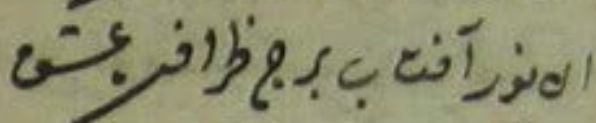
إهز

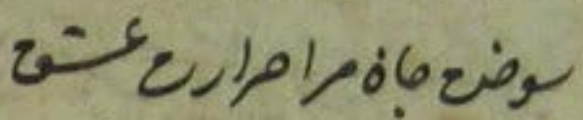

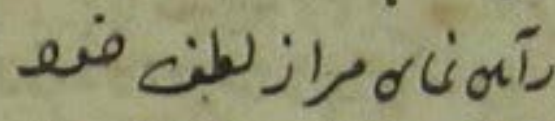
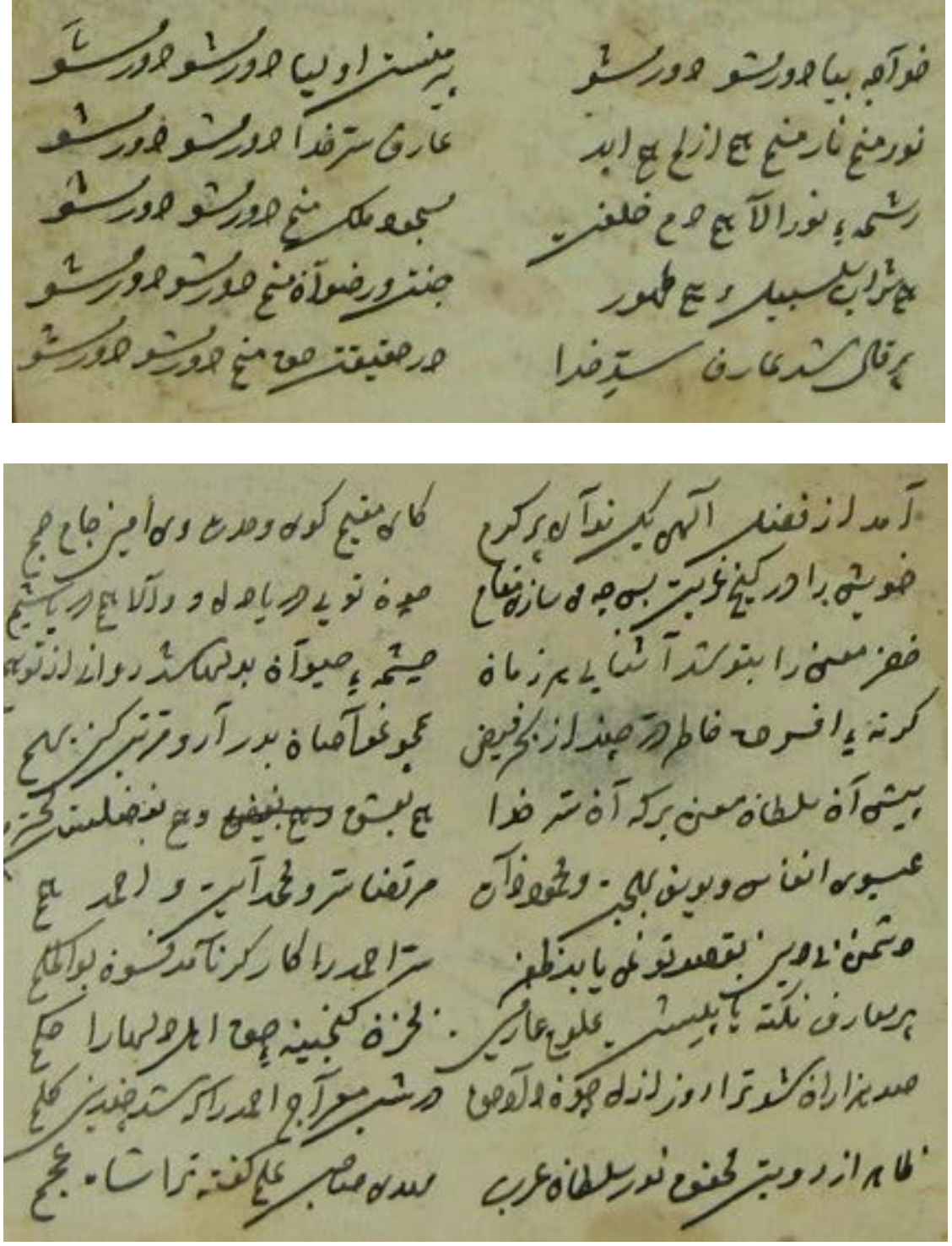


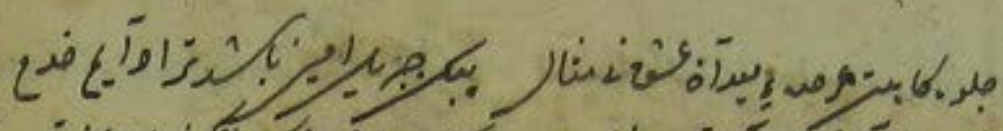

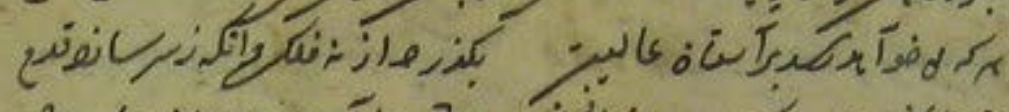
\& \& $^{6}$ :

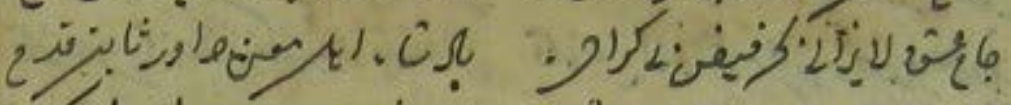
(ק) (j)

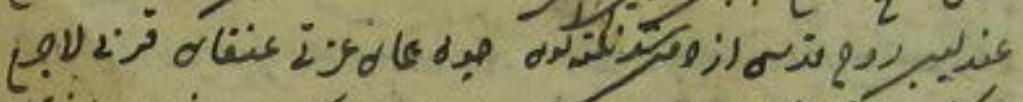

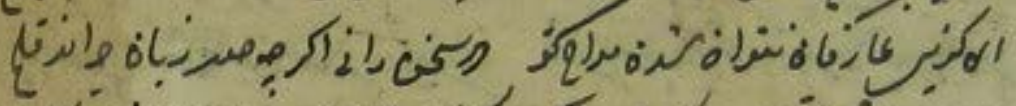
(ب)

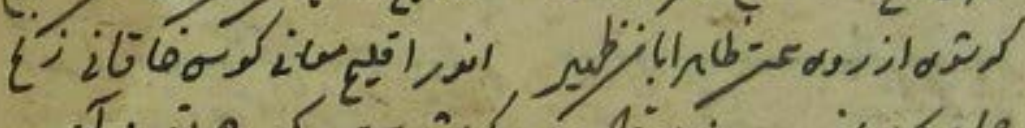

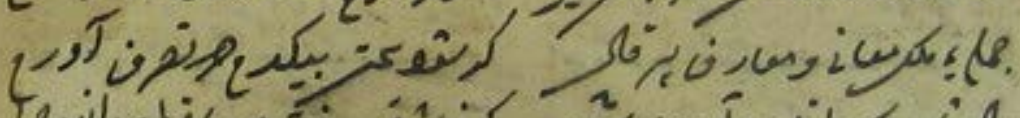

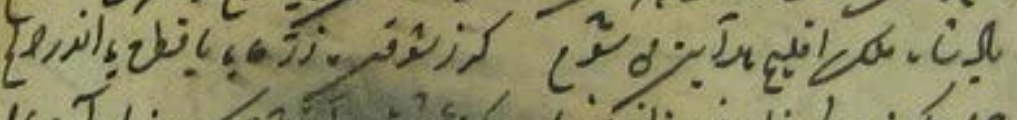
हैe

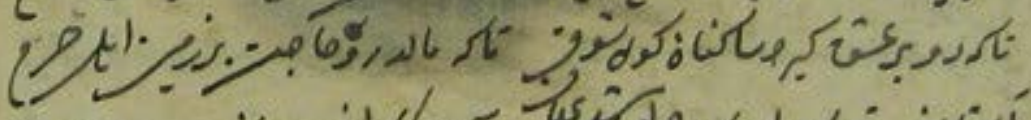

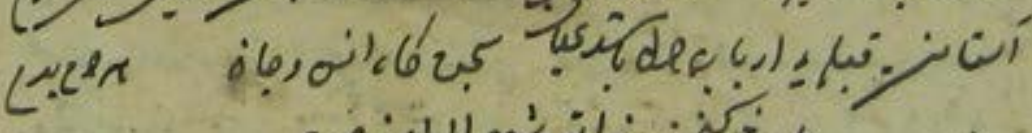

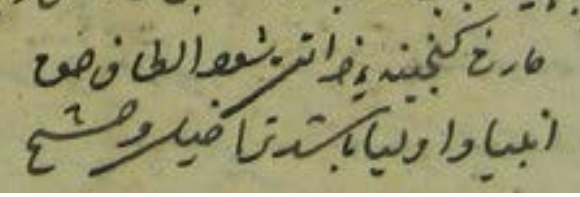

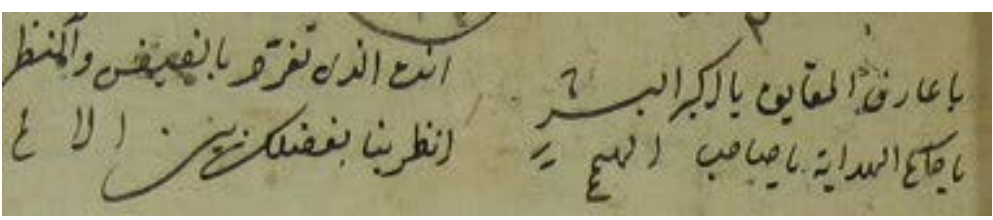

"

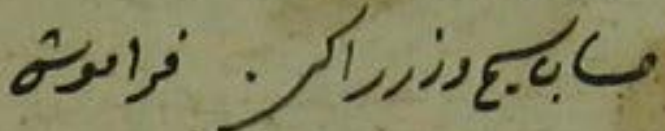

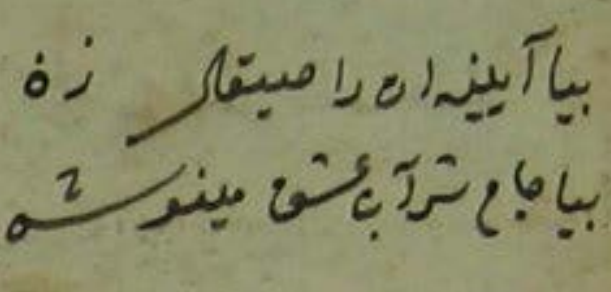

in Is

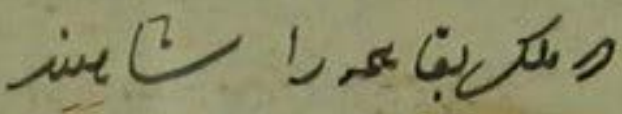

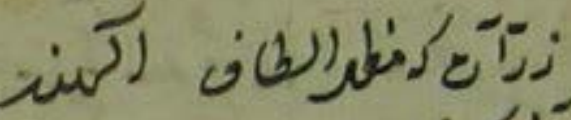

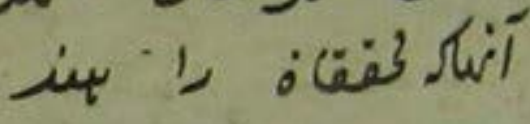



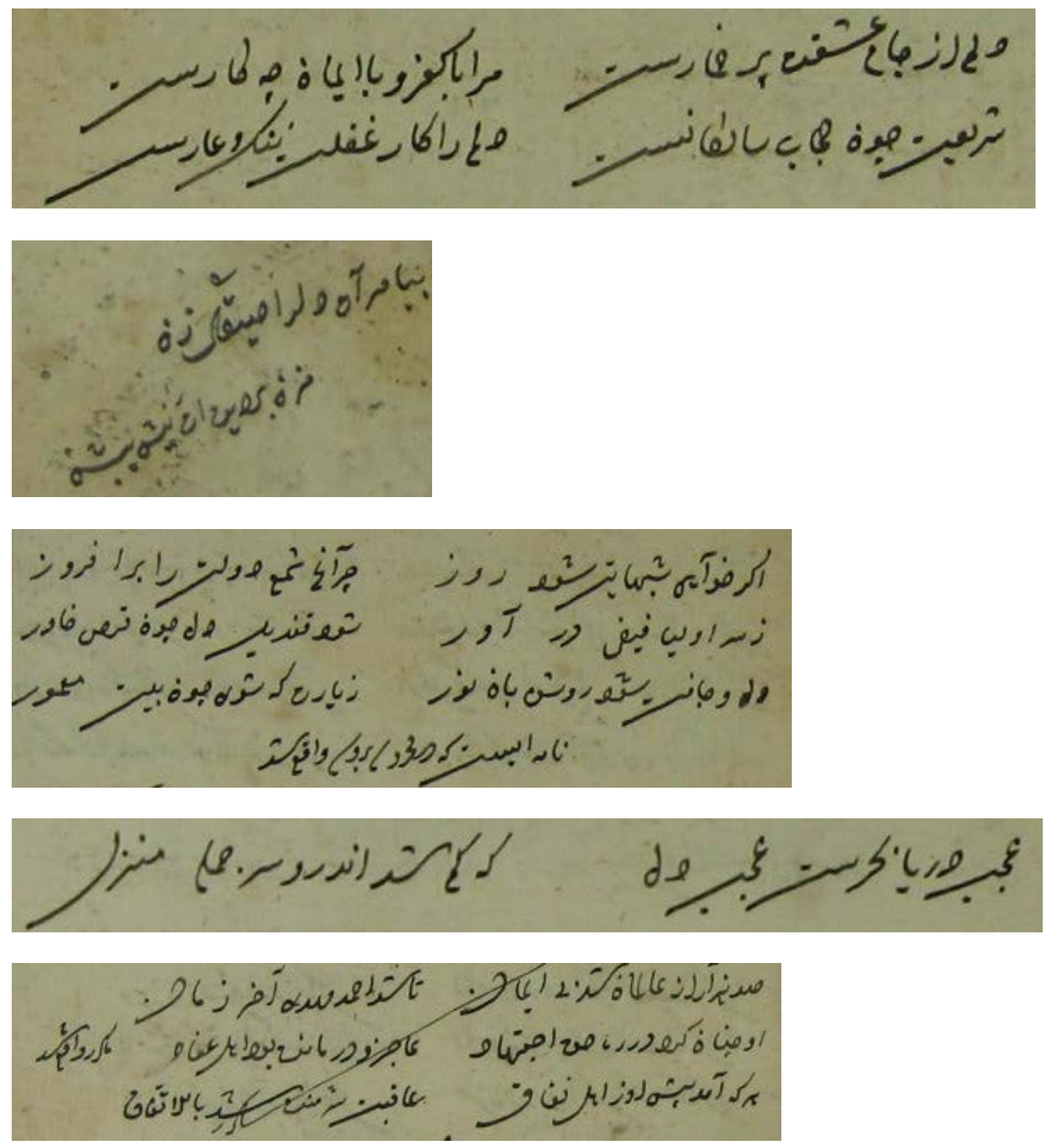

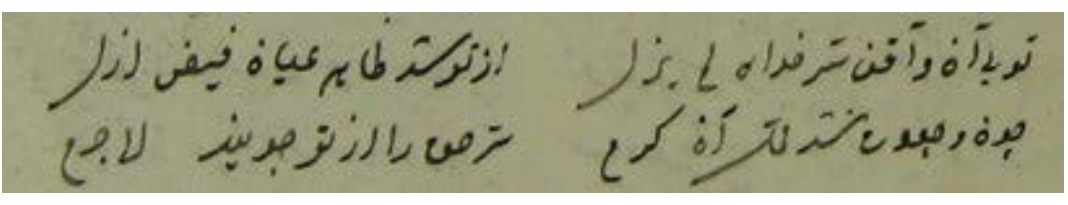

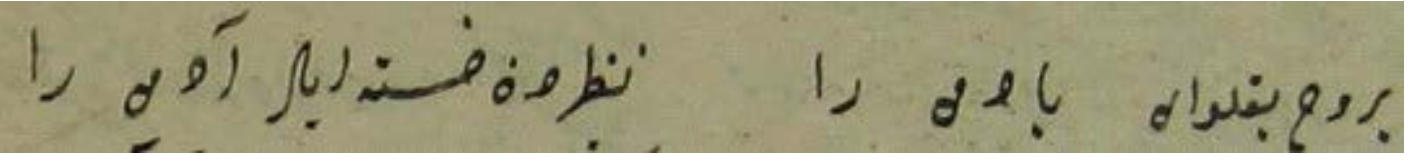



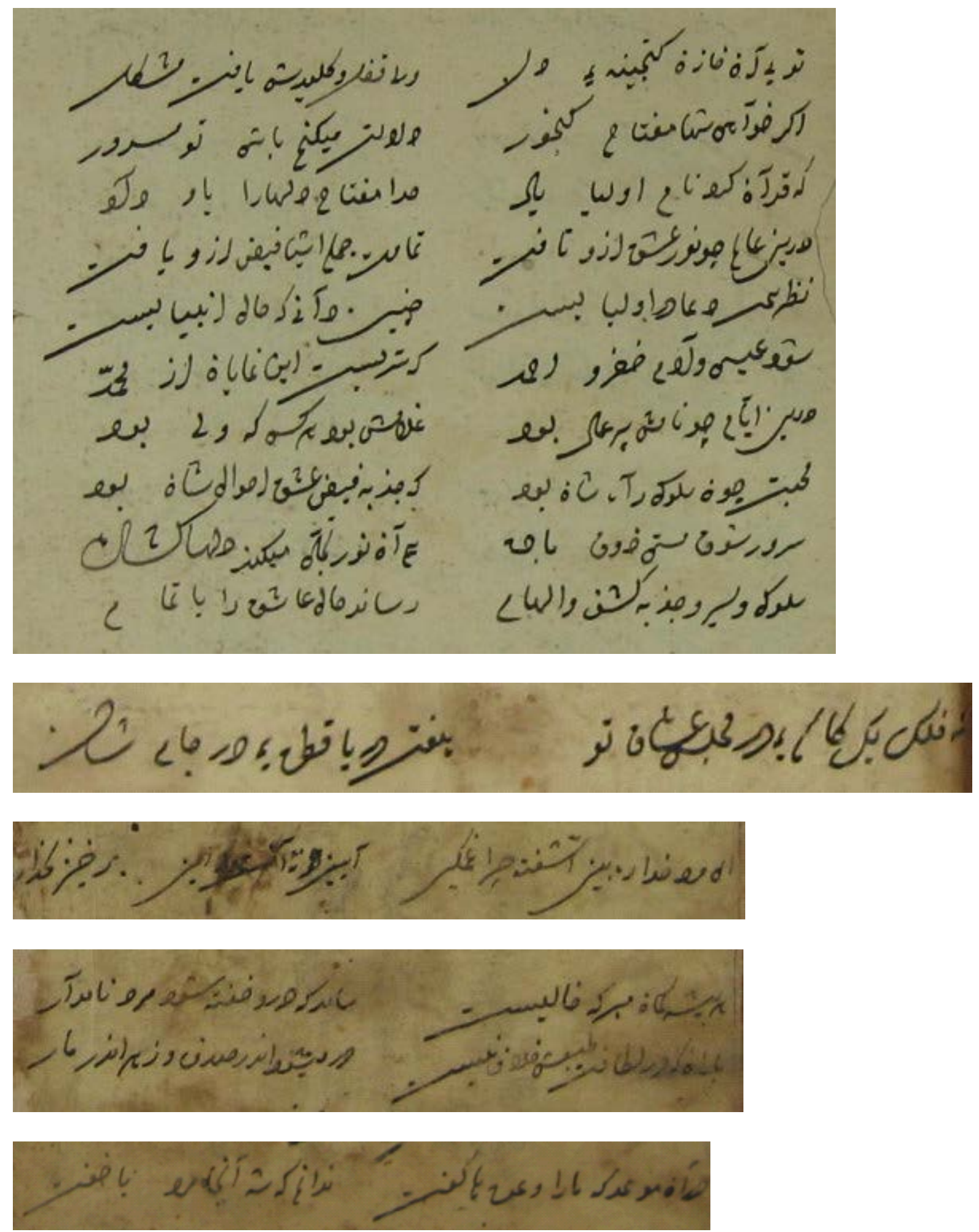

Pirkal Divanı'nda kullanılan nazım şekilleri ile ilgili bilgi vermenin de yerinde olacağını düşünmekteyiz. Şair, Divan'da nazım şekli olarak mesnevi, gazel, müsemmen, nazm ve muhtelif manzumelere (Kıtalar-Müfredler-Mısralar-Rubâîler-Lugazler) yer vermiştir.

\section{Mesnevi}

Pirkal Divanı'nda altı mesnevi mevcuttur. İkinci mesnevi yedi beyit, altıncı mesnevi sekiz beyit, üçüncü mesnevi on üç beyit, dördüncü mesnevi on yedi beyit, beşinci mesnevi on sekiz 
beyit, birinci mesnevi otuz bir beyittir. Mesnevilerin tamamı 'mefầ'îlün mefâ'îlün fa'ûlün'vezniyle yazılmıştır.

\section{Gazel}

Divanda iki yüz yirmi bir gazel yer almaktadır. Bu gazellerden altı tanesi Farsça yazılmıştır. Gazellerin biri bir beyitli, biri iki beyitli, ikisi üç beyitli, dördü dört beyitli, yüz otuz biri beş beyitli, yirmi dördü altı beyitli, otuz dördü yedi beyitli, dokuzu sekiz beyitli, üçü dokuz beyitli, üçü on beyitli, biri on bir beyitli, biri on iki beyitli, ikisi on üç beyitli, biri on dört beyitli, biri on beş beyitli, biri on altı beyitli, biri yirmi dokuz beyitlidir.

Gazellerde altı vezin kalıbı kullanılmıştır. Gazellerden yüz biri 'Fâ'ilâtün Fâ'ilâtün Fâ'ilün', otuzu 'mefâ'’̂lün mefâ'îlün fa'ûlün', yetmiş ikisi 'Fâ'ilâtün Fâ'ilâtün Fâ'ilâtün Fâ'ilün', biri 'mefâ'îlün fa'ûlün mefâ'îlün fa'ûlün', biri ‘müstef'ilün müstef'ilün müstef'ilün müstef'ilün', dördü 'mefâ'îlün mefâ'îlün mefâ'îlün mefâ'îlün' aruz kalıplarıyla yazılmıştır. Dört gazelin de vezin birliği bulunmamaktadır.

\section{Müsemmen}

Divanda beş bölümden oluşan kırk mısralı bir müsemmen mevcuttur. Aruzun 'mefâ'îlün mefâ'îlün fa'ûlün' kalıbıyla yazılmıştır.

\section{Nazm}

Divanda Farsça yazılmış bir nazm mevcuttur. Yirmi altı beyitten oluşmaktadır.

\section{Muhtelif manzumeler (Kitalar-Müfredler-Misralar-Rubâîler-Lugazler)}

Divanda yüz otuz iki muhtelif manzume bulunmaktadır. Bu manzumelerin on altısı Farsça yazılmıştır. Muhtelif manzumelerin elli yedisi bir beyitli, kırk sekizi iki beyitli, on biri üç beyitli, dördü dört beyitli, biri beş beyitli, ikisi yedi beyitli, biri sekiz beyitli, biri dokuz beyitli, biri on beyitli, biri on bir beyitli, biri on üç beyitli, biri on beş beyitli, biri otuz beş beyitlidir.

Muhtelif manzumelerde beş aruz kalıbı kullanılmıştır. Muhtelif manzumelerden kırk biri 'Fâ'ilâtün Fâ'ilâtün Fâ'ilün', kırk ikisi 'mefâ'îlün mefâ'îlün fâ'ûlün', yirmi biri 'Fâ'ilâtün Fâ'ilâtün Fâ'ilâtün Fâ'ilün', üçü 'mefâ'îlün mefâ'îlün mefâ'îlün mefâ'îlün', ikisi 'mef'ûlü fầilâtü mefâ'îlü fâ'ilün' aruz kalıplarıyla yazılmıştır.

Divânın Nüsha Tavsifi

Eserin adı: Pirkâl Dîvânı

Müellifi: Pirkâl

Bulunduğu Kütüphane: Süleymaniye Kütüphanesi, Giresun Yazmaları bölümü, nu:181

Yaprak sayısı: 52

Divanın ölçüleri: 210x150, 140x100

Hat: Dîvâni kırması

Satır sayısı: 16

Tezhip ve minyatür: Yok

Muhtevâ: 6 mesnevî, 221 gazel, 1 müsemmen, 1 nazm, 132 muhtelif manzume(Kitalarmüfredler-misralar-lugazler)

Eserin baş kısmı: 
Virür ol denlü ana işve-i hûb

Dil-i âşık olur aşüfte meczûb (Mes. 1/1)

Eserin son k1smı:

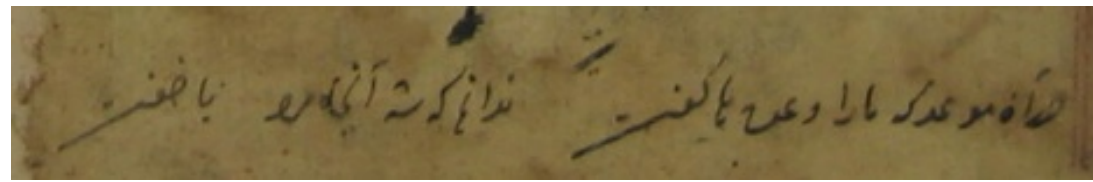

Pirkâl'in şiirlerinde sıklıkla nasihatlere rastlamaktayız.

Mansıb-1 uşşâkı pest itme sakın

Aşkdurur çün zirve-i ahlâk-1 evc (G. 37/2)

Ferd-i vâhid mest-i Hakk ol ey gönül

Çift olup dünyâ ile sen olma zevc (G. 37/3)

Pirkâl dünyâya sunmaz destini

İstemez dünyâ ile olmaga zevc (G. 37/5)

Kimseye itme hakâret ile nazar sen ârif ol

Acı sözden k'ey sakıngıl olmasun bu nâm-1 telh (G. 44/3)

Tevâcüd ehli ile hoş-revân ol

Egiler meclisinden sen nihān ol (Mes. 1/30)

\section{Sonuç}

16. yüzyıl, Divan Edebiyatı'nın söyleyiş gücü ve anlam zenginliğinin zirveye çıktığı bir dönemdir. Bu yüzyılda Fuzuli ve Baki gibi Divan Edebiyatı'nın en önemli şairleri yetişmiştir. Tanıtmaya çalıştığımız bu yazma eserin de aynı yüzyılda kaleme alınmış olması ona ayrıca bir değer atfetmektedir. Diğer taraftan Hurufilik üzerine çalışma yapan araştırmacıların da istifade edebilecekleri bir eserdir. 


\section{REFERENCES}

- AKSU, Hüsamettin (1998). "Hurufilik", c.XVIII, Türkiye Diyanet Vakfı İslam Ansiklopedisi, s. 408-412.

- BASHİ, Shahzad (2012). Fazlullah Esterabadi ve Hurufilik, Çev: Ahmet Tunç Şen, İstanbul: Kitap Yayınevi.

- GÖLPINARLI, Abdülbaki (1964). Bektaşilik- Hurufilik ve Fadl Allah'ın Öldürülmesine Düşülen Üç Tarih, Şarkiyat Mecmuası, sy. 5, s. 15-22.

- GÖLPINARLI, Abdülbaki (1973). Hurufilik Metinleri Kataloğu, Ankara: Türk Tarih Kurumu Yay.

- İSEN, Mustafa (1994). Künhü’l-Ahbar'ın Tezkire K1smı/Gelibolulu Ali Mustafa Efendi, Ankara: Atatürk Kültür, Dil ve Tarih Yüksek Kurumu Atatürk Kültür Merkezi.

- KANSIZOĞLU, Yakup (2004). Şifreci Yanılg1: Hurufilik Tasavvuru, Harf Gizemciliği ve Kur'an Yorumuna Olan Etkileri, İstanbul: Rağbet Yay.

- KILIÇ, Filiz (2010). Meşâirü'ş-şuara: İnleme-Metin./Aşsk Çelebi, İstanbul: İstanbul Araştırmaları Enstitüsü Yay.

- KUTLUK, İbrahim (2014). Tezkiretü'ş-Şuara/Kınalızade Hasan Çelebi, haz: İbrahim Kutluk, Ankara: Türk Tarih Kurumu Yay.

- KÜÇÜK, İslam (2008). "Pirkal Dîvânı (İnceleme-Metin), Basılmamış Yüksek Lisans Tezi, İstanbul: Fatih Üniversitesi Sosyal Bilimler Enstitüsü.

- MUHTAR, Cemal (1986). Hurufi Türk Şairleri, Marmara Üniversitesi İlahiyat Fakültesi Dergisi, İstanbul, sy. 4, s. 219-226.

- SUNGURHAN, Aysun (1994). Beyani Tezkiresi: İnceleme-Tenkitli Metin, Ankara: Gazi Üniversitesi Sosyal Bilimler Enstitüsü.

- TÖKEL, Dursun Ali (2003). Divan Şiirinde Harf Simgeciliği, Ankara: Hece yay.

- USLUER, Fatih (2009). Hurufilik: İlk Elden Kaynaklarla Doğuşundan İtibaren, İstanbul: Kabalcı Yayınevi.

- USLUER, Fatih; ŞENÖDEYİCI, Özer; ARIKOĞLU, İsmail ( 2014). Hurufilik Bilgisi Ferişteoğlu Abdülmecid Külliyatı, Ankara: Gece Kitaplığı.

- ÜNVER, Mustafa (2003). Hurufilik ve Kur'an: Nesimi Örneği, Ankara: Fecr Yay. 